\title{
Laboratory investigation of Accuracy of Impression Materials for Border Molding
}

\author{
Dobromira Shopova, Diyan Slavchev \\ Department of Prosthetic Dentistry, Faculty of Dental Medicine, Medical University of Plovdiv, Plovdiv, Bulgaria.
}

Corresponding author: Dobromira Shopova, Department of Prosthetic Dentistry, Faculty of Dental Medicine, Medical University of Plovdiv, 3 Christo Botev Blvd., 4000 Plovdiv, Bulgaria; E-mail: dent.shopova@gmail.com; Tel: +359887417078

Received: 01 June $2018 \diamond$ Accepted: 28 Feb $2019 \diamond$ Published: 30 Sep 2019

Citation: Shopova D, Slavchev D. Laboratory investigation of accuracy of impression materials for border molding. Folia Med (Plovdiv) 2019;61(3):435-43: doi: 10.3897/folmed.61.e39351

Introduction: Border molding of the edge of the individual impression tray is an important stage of prosthetic treatment of edentulous jaws, which often depends on the final result of the treatment. Classical thermoplastic impression materials for border molding have positive qualities that make them preferable by clinicians for their hardness, unlimited manipulation time and high impression sharpness. Modern silicone impression materials for border molding have long manipulating time and appropriate viscosity to allow dentists to perform functional tests.

Aim: To determine the accuracy of different impression materials for border molding of individual impression trays.

Materials and methods: Four impression materials for border molding were laboratory tested: Kerr impression compound green sticks and thermoplastic GC Iso functional sticks, additive type silicone Detaseal function and condensation type silicone sta-seal $\mathrm{f}$. A modified individual impression tray designed by authors was used, allowing for laboratory load and stability. Ten impressions were taken and their formed edges were measured at 10 points three times - immediately after hardening/elasification, and 24 hours and 48 hours after hardening/elasification.

Results: The results were analysed using ANOVA repetition analysis, where a statistically insignificant difference in the accuracy of three of the impression materials for border molding was established, except the C-type of silicone.

Conclusions: Good manipulative qualities and measured accuracy in laboratory tests define these materials as very good for border molding procedures.

\section{Key words:}

border molding, impression material, complete dentures

\section{INTRODUCTION}

Border molding of individual impression trays is an important stage in the prosthetic treatment plan for edentulous jaws, which determines the stability of the prosthesis during rest and function. Applying the border molding procedures reduces the deformation of the alveolar crest and the border soft tissues, resulting in increased retention and stability. ${ }^{1}$ Mucostatic methods lead to an inadequate impression and in many cases cause failure. ${ }^{2-4}$ In a comparative study, it was found that the force required to detach a denture made with functional and non-functional impression technique was $53 \%$ greater. $^{5}$ In the case of shortened treatment without border molding, there was a statistically significant difference in the number of visits and the number of decubitus ulcers after the insertion of the complete dentures. ${ }^{6}$ 
Of significance for a correct impression of the gingivobuccal sulcus is not only its depth but also its width, a factor which is often underestimated. ${ }^{7,8}$ The most commonly applied border moulding tests are the Herbst tests for border molding. ${ }^{9}$ The determination of the borders of the prosthesis is influenced by anatomical structures - muscles, muscular and soft-tissue gripping. ${ }^{5,10}$ In the distal region, the transverse line is located in the paratuberal space to facies infratemporalis maxillae. An asymmetry between the left and right halves of upper and lower jaws has been established. ${ }^{11,12}$

The impression accuracy depends not only on what type of technique we use, but also on the type of the impression material used for the purpose. The choice of material depends on the anatomical features of the prosthetic field. ${ }^{9,13}$ Solid, thermoplastic and silicone impression materials can be used for border molding. ${ }^{14,15}$ Thermoplastic materials include impression compound, waxes and wax masses with a working temperature range. They should be used carefully on retentive arches. ${ }^{16,17}$

Additive type silicones show overall stability up to 7 days after impression taking, but despite the proper storage of many authors recommended up to 48 hours. ${ }^{18,19}$ Condensation type silicones have polymerization reaction associated with side product release, which decrease their volume. ${ }^{20}$ Furthermore volume change is possible and deviation. ${ }^{21}$ The linear change is not the same in the three dimensions of the impression. ${ }^{22}$ Functional silicone impression materials are a separate group having prolonged manipulative time and appropriate viscosity to allow performing the functional tests. ${ }^{23,24}$

During the clinical impression procedure, the minimum applied pressure is $1 \mathrm{~kg} / \mathrm{cm}^{2}$, which is unequal distributed bigger on the alveolar ridge, less on the midline. ${ }^{25}$

\section{AIM}

To determine the accuracy of different impression materials for border molding of individual impression trays.

\section{MATERIALS AND METHODS}

Two thermoplastic and two silicone materials for bordermolding were subjected to a laboratory test - impression compound green sticks (Kerr), thermoplastic material GC Iso functional sticks (GC), additive type silicone (Detaseal function - Detax) and condensation type silicon (Sta-seal f - Detax) (Figs 1-4).

It was used modified individual impression tray by author's design. It was made of a two-layer light-polymerizing base plate. In the area of the gingivobuccal sulcus, the vestibular layer was formed $1 \mathrm{~mm}$ higher than the palatal and a chase was formed between them as a mechanical retention.
The palatal inclination was filled with material up to alignment with the level of the alveolar ridge. This impression tray was used to taking an impression of a model, obtained using a 3D printer technology with individual values of the gingivobuccal sulcus width and $2 \mathrm{~mm}$ depth (Fig. 5).

For proper tempering of thermoplastic materials according to the manufacturer's recommendations, a laboratory setting was invented, including a control box and a water bath. The operating temperature for GC Iso functional sticks was $40^{\circ} \mathrm{C}$, for Impression compound green sticks Kerr - $50^{\circ} \mathrm{C}$ (Fig. 6).

After manual mixing of the components of silicone materials, the impression mass was shaped like an elongated cylinder and placed at the edges of the individual impression tray. Thermoplastic materials were melted in our Laboratory setting for controlled tempering, and again the material was extended and placed at the custom tray's edge. The composition (a model, an individual impression tray and an impression material) was placed immediately in the hydraulic dental press. The impression material filled the gingivobuccal sulcus on the model. During the elastification / hardening of the impression material, the model and the individual impression tray were loaded with $40 \mathrm{~kg}$ (40 bar), corresponding to the minimum pressure impression taking and the prosthesis area. The composition was retained in the press until the complete elastification/hardening of the material. The impression mass that was out of the custom tray was cut off (Figs 7, 8).

10 impressions were taken, and their formed edges were measured at 10 points ( 5 symmetrical points on each side) three times - immediately after elastification/hardening, and after 24 and 48 hours (Fig. 9).

The results were tabulated, statistically processed and visualized using Microsoft Office Excel 2010.

\section{RESULTS}

ANOVA repetition analysis was used to process the data obtained to compare more than two group means. The results were also confirmed by Tukey, Bonferroni and Duncan's validated tests.

\section{Impression compound green sticks (Kerr)}

According to mean value, there wasn't difference between the three time intervals $(2,935 \mathrm{~mm})$. This describes the impression compound as a very stable material (Table 1).

We found no significant differences between the different time measurements for this thermoplastic material (Tables 2,3).

\section{GC Iso functional sticks (GC)}

The mean value decreased by $0.023 \mathrm{~mm}$ for "immediate / 24 hours" interval and $0.014 \mathrm{~mm}$ for "24/48 hours" interval. There was a minimal shrinkage, more pronounced in the first 24 hours after the impression taking $(0.023 \mathrm{~mm})$ (Table 4). 


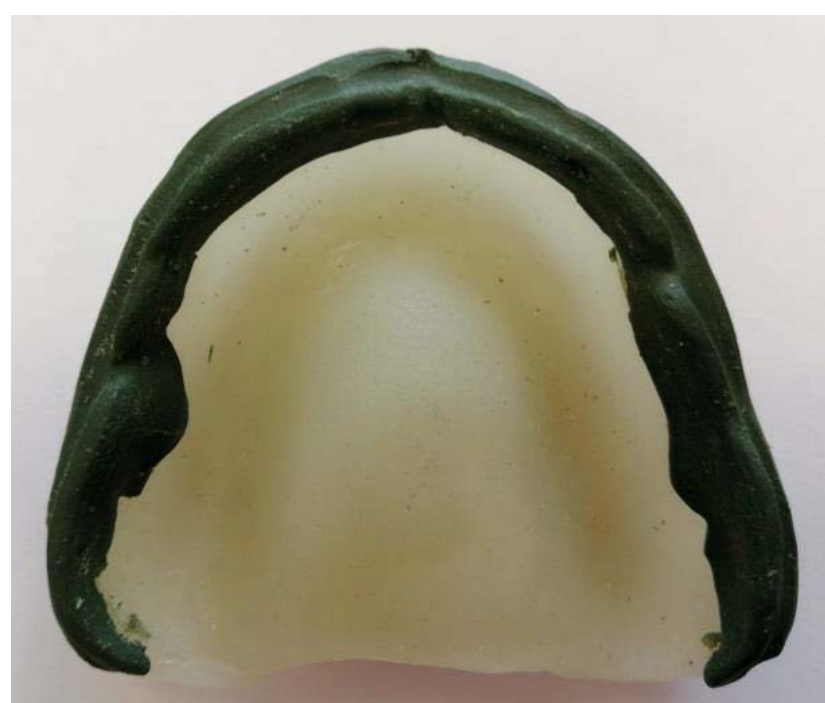

Figure 1. Impression compound ${ }^{*}$ after border molding procedure.

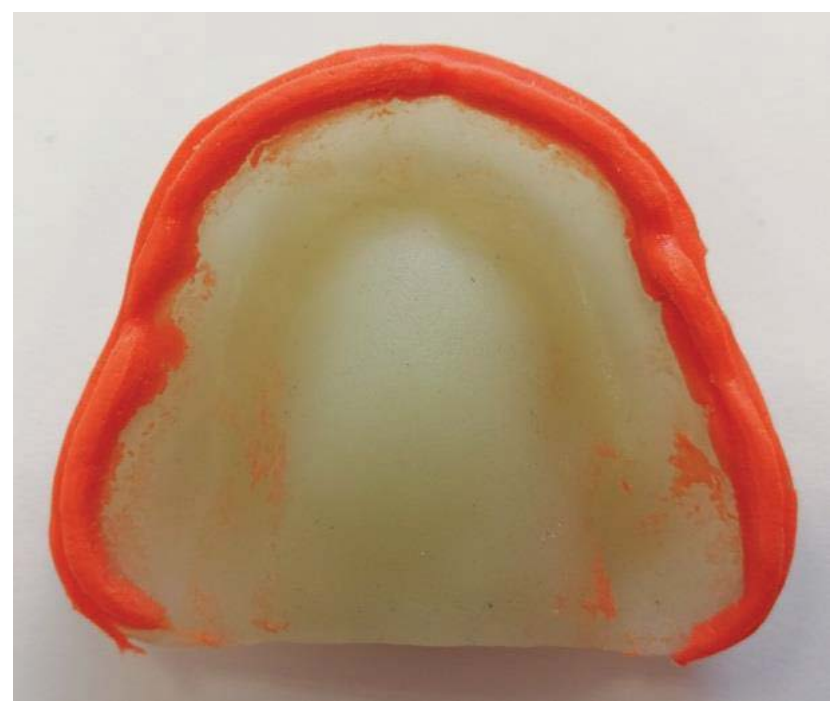

Figure 3. Detaseal function material ${ }^{\star * *}$ after border molding procedure.

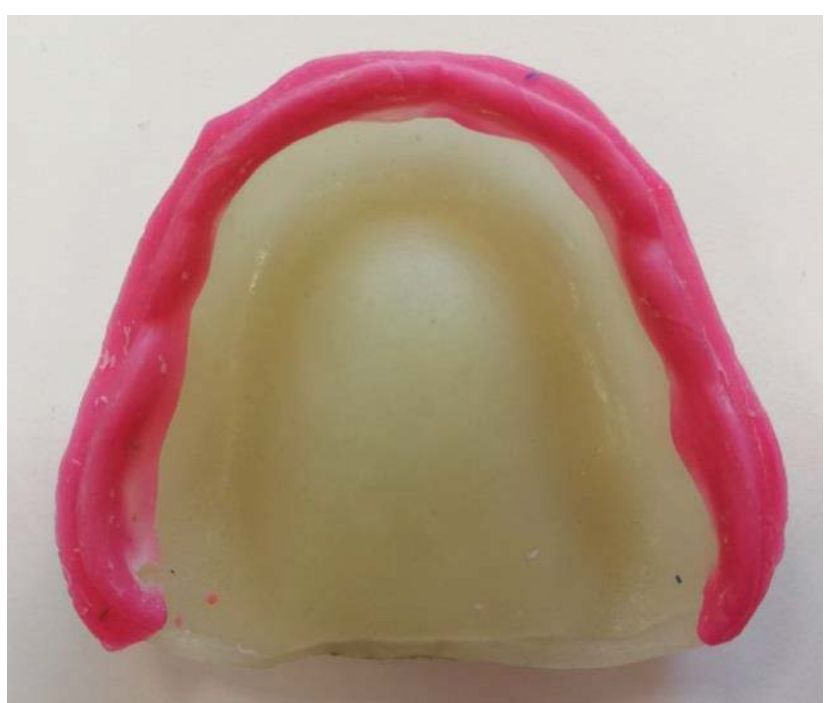

Figure 2. GC Iso functional sticks ${ }^{* *}$ after border molding procedure.

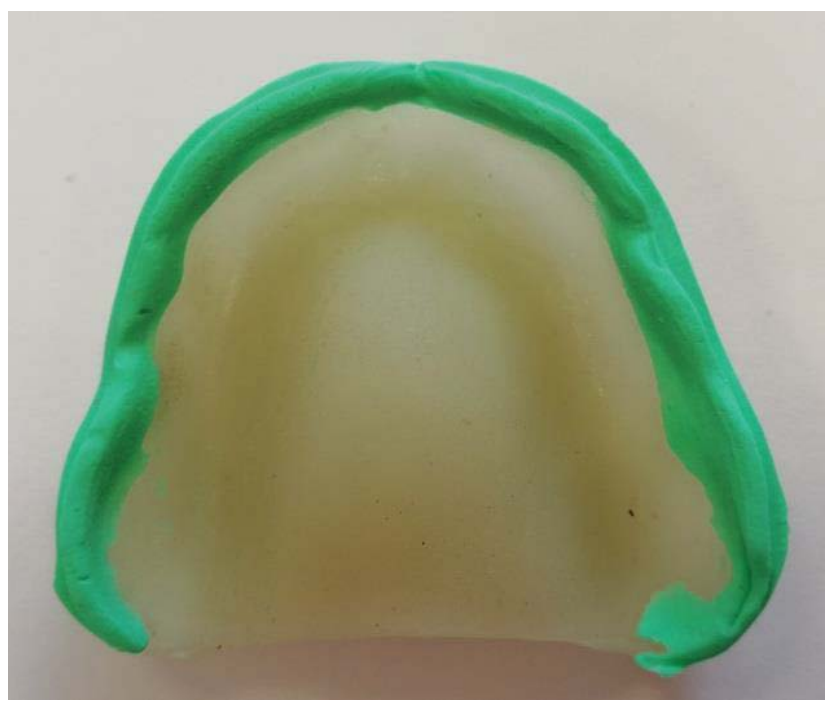

Figure 4. Sta-seal $\mathrm{f}$ material ${ }^{* * *}$ after border molding procedure.

${ }^{\star}$ Impression compound - green sticks (Kerr); ${ }^{\star \star} \mathrm{GC}$ Iso functional sticks (GC); ${ }^{* *}$ Detaseal function (Detax); ${ }^{* * \star}$ Sta-seal $\mathrm{f}$ (Detax)

In the processing of the data obtained from the thermoplastic material GC Iso functional sticks no statistically significant difference was found between the different time measurements (Tables 5, 6).

\section{Detaseal function (Detax)}

After analyzing the mean values, a minimal shrinkage by $0.02 \mathrm{~mm}$ was established in the intervals immediately and after 24 hours, and by $0.023 \mathrm{~mm}$ at " $24 / 48 \mathrm{~h}$ " interval (Table 7).

There was no significant difference between the different time measurements for the additive type of silicone Detaseal function (Tables 8, 9).

\section{Sta-seal $f($ Detax $)$}

From the movement of the mean values it was visible that they decreased and significant shrinkage was established, especially pronounced during the first 24 hours - $0.174 \mathrm{~mm}$. The change was minimal by $0.01 \mathrm{~mm}$ in the range between 24 and 48 hours (Table 10).

The data obtained from the condensation type Sta-seal $f$ silicon showed a statistically significant difference between the initial moment and the 24 hour sample and the initial moment and the 48 hour sample. A statistically significant difference was not found between 24 and 48 hours (Tables 11, 12). 


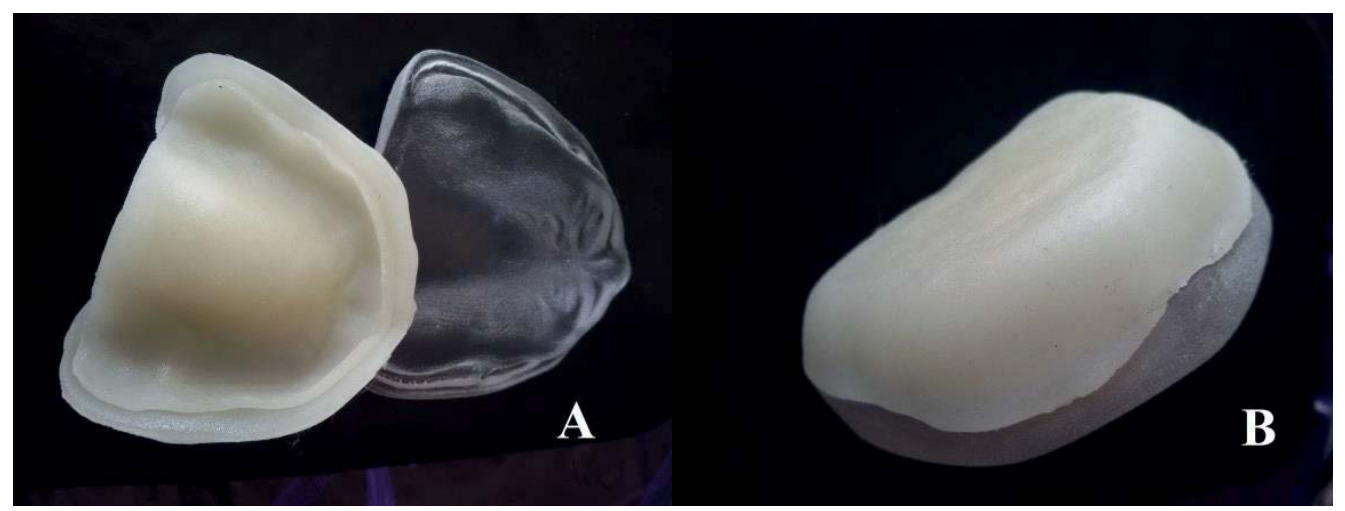

Figure 5. Modified individual impression tray (A) and a model with individual values made on 3D printer technology (B)

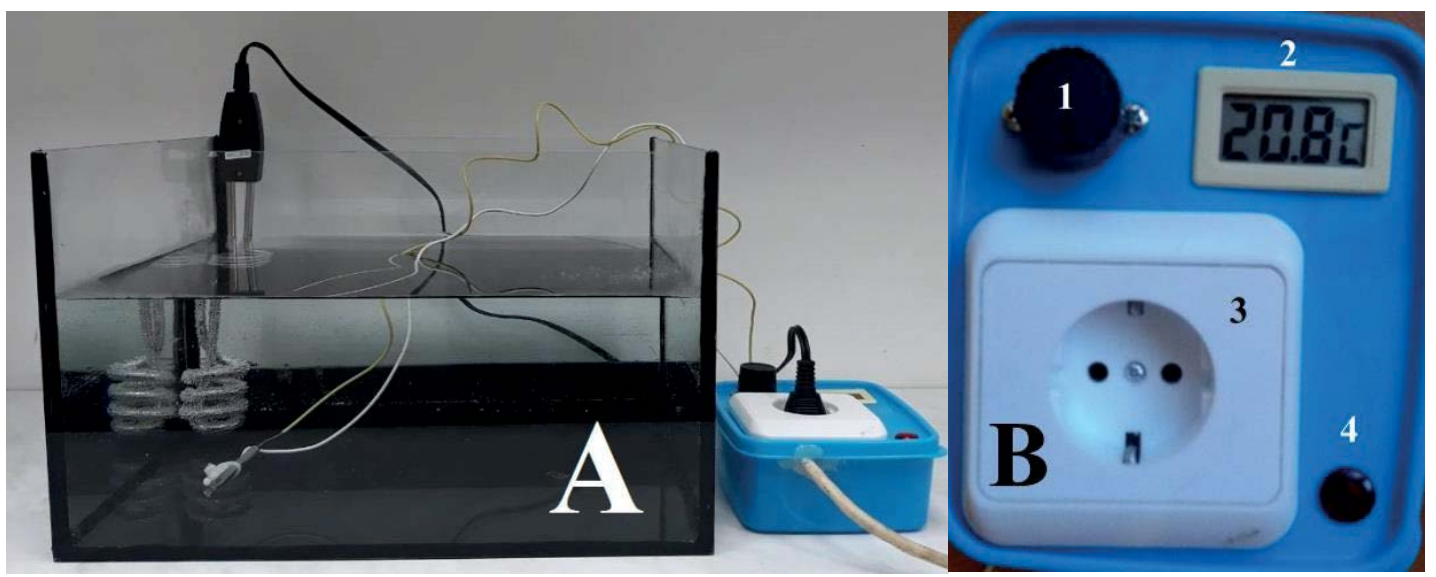

Figure 6. Laboratory setting for controlled tempering (A) and a control box (B)

1. thermoregulator $\left(5^{\circ} \mathrm{C}-75^{\circ} \mathrm{C}\right)$; 2 . digital thermometer; 3. contact for switching on the heater; 4 . signal light illuminated when the heater is operating.

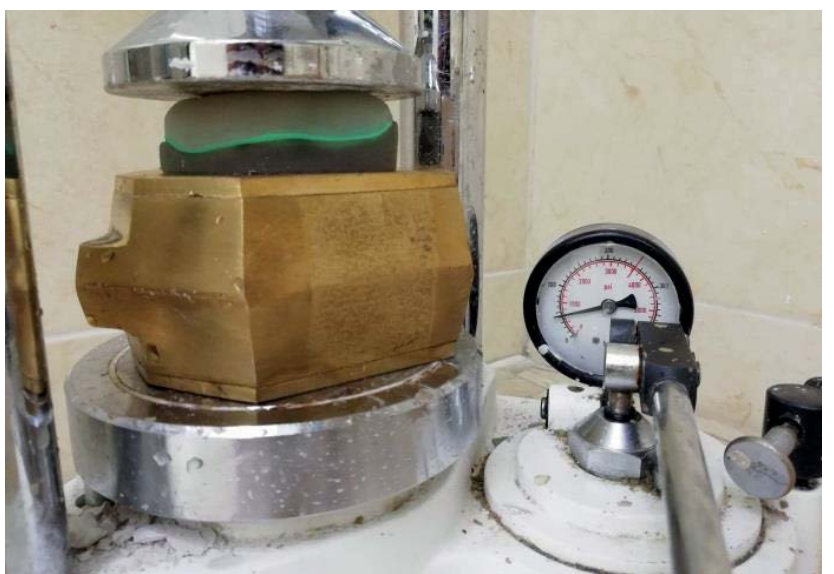

Figure 7. Laboratory composition of taking an impression.
The observed statistically significant differences are not of clinical relevance for the purpose of border molding the individual impression tray.

An interesting fact is the variability between the average group values of the tested materials. Both thermoplastic and both silicone materials are grouped together with close rates. At the initial moment after hardening / elastification the material, the largest volume has the synthetic resin GC ( $2.960 \mathrm{~mm})$, followed by Kerr impression compound (2.935 $\mathrm{mm}$ ). The difference between them was $0.025 \mathrm{~mm}$. With a significantly smaller volume of silicone materials - Sta-seal $\mathrm{f}(2,753 \mathrm{~mm})$ and Detaseal function $(2,690 \mathrm{~mm})$. Their difference was $0.063 \mathrm{~mm}$. However, when comparing the two groups, the difference varies from $0,18 \mathrm{~mm}$ to $0.27 \mathrm{~mm}$. This discrepancy is shown in Table 13.

\section{DISCUSSION}

Laboratory tests show accuracy and stability, as described 


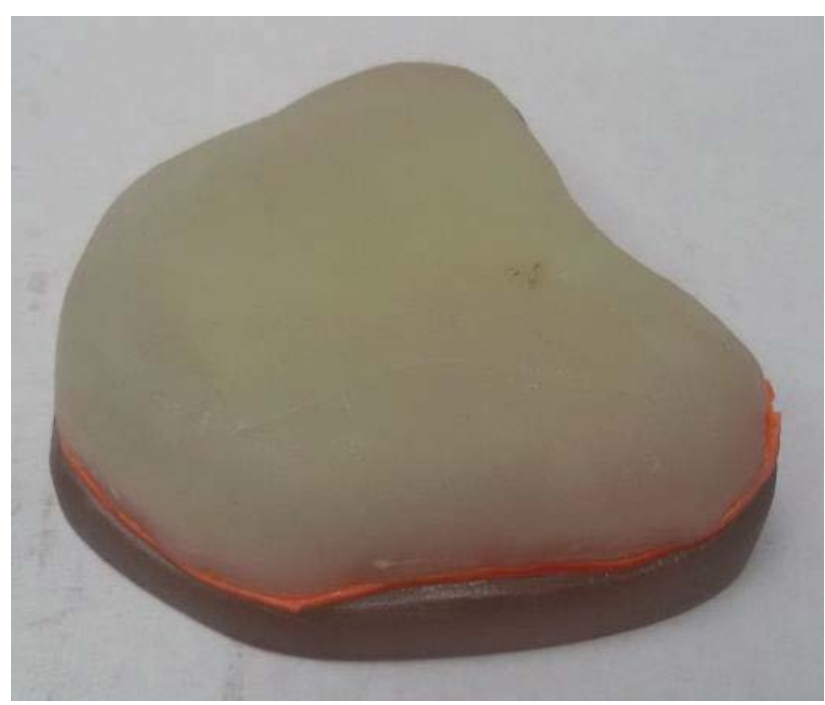

Figure 8. Laboratory made impression.

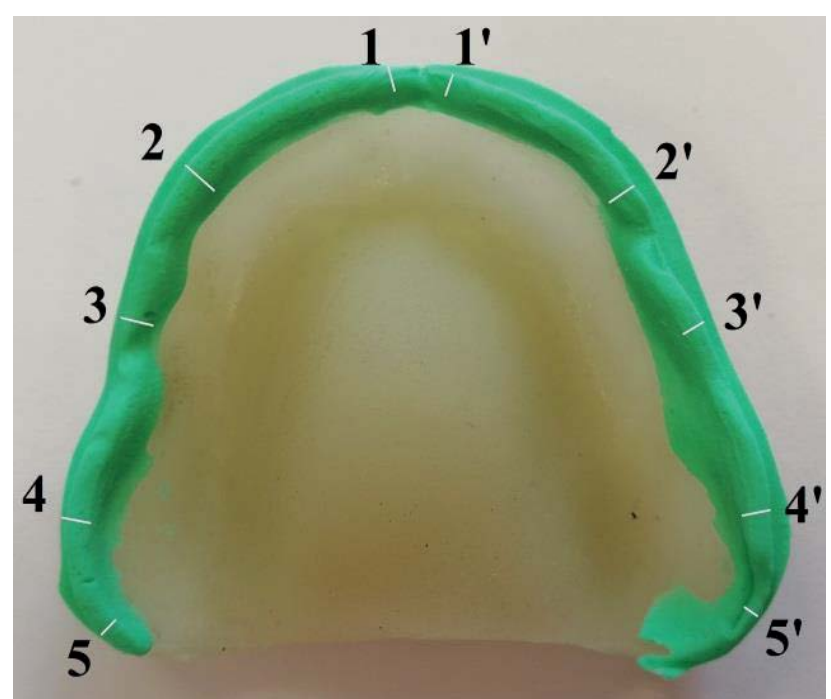

Figure 9. Points of measurement.

Table 1. Statistical descriptive parameters for impression compound green sticks (Kerr)

\begin{tabular}{lcccc}
\hline & Minimum & Maximum & Mean & Standard deviation \\
\hline Immediately & 2.460 & 3.340 & 2.935 & 0.207 \\
After 24 h & 2.470 & 3.340 & 2.935 & 0.208 \\
After 48 h & 2.470 & 3.360 & 2.935 & 0.208 \\
\hline
\end{tabular}

Table 2. ANOVA repetition analysis for impression compound green sticks - Kerr

\begin{tabular}{lccccccc}
\hline \multicolumn{1}{c}{ Source } & DF & $\begin{array}{c}\text { Sum of } \\
\text { squares }\end{array}$ & $\begin{array}{c}\text { Mean } \\
\text { squares }\end{array}$ & F & Pr $>$ F & \multicolumn{2}{c}{ Adj. Pr $>$ F } \\
G-G & $\begin{array}{c}\text { Adj. Pr }>\text { F } \\
\text { H-F }\end{array}$ \\
\hline Repetition & 2 & 0.000 & 0.000 & 0.161 & 0.851 & 0.840 & 0.844 \\
Error & 198 & 0.015 & 0.000 & & & & \\
\hline
\end{tabular}

Table 3. Tukey test to establish a difference between time intervals (Impression compound green sticks Kerr)

\begin{tabular}{lccccc}
\hline \multicolumn{1}{c}{ Contrast } & Difference & Standardized difference & Critical value & Pr $>$ Diff & Significant \\
\hline now/24 hours & 0.001 & 0.024 & 2.356 & 1.000 & No \\
now/48 hours & 0.000 & 0.010 & 2.356 & 1.000 & No \\
24 h/48 h & 0.000 & 0.014 & 2.356 & 1.000 & No \\
Tukey's d critical value: & & & 3.331 & & \\
\hline
\end{tabular}

Table 4. Statistical descriptive parameters for GC Iso functional sticks (GC)

\begin{tabular}{lcccc}
\hline & Minimum & Maximum & Mean & Standard deviation \\
\hline Immediately & 2.550 & 3.460 & 2.960 & 0.213 \\
After 24 h & 2.540 & 3.440 & 2.937 & 0.213 \\
After 48 h & 2.520 & 3.420 & 2.923 & 0.214 \\
\hline
\end{tabular}


D. Shopova et al

Table 5. ANOVA repetition analysis for GC Iso functional sticks

\begin{tabular}{lccccccc}
\hline Source & DF & Sum of squares & Mean squares & F & Pr $>$ F & Adj. Pr $>$ F G-G & Adj. Pr $>$ F H-F \\
\hline Repetition & 2 & 0.069 & 0.034 & 864.510 & $<0.0001$ & $<0.0001$ & $<0.0001$ \\
Error & 198 & 0.008 & 0.000 & & & & \\
\hline
\end{tabular}

Table 6. Tukey test to establish a difference between time intervals (GC Iso functional sticks)

\begin{tabular}{lccccc}
\hline \multicolumn{1}{c}{ Contrast } & Difference & Standardized difference & Critical value & Pr $>$ Diff & $\begin{array}{c}\text { Signifi- } \\
\text { cant }\end{array}$ \\
\hline now/24 hours & 0.037 & 1.223 & 2.356 & 0.441 & No \\
now/48 hours & 0.022 & 0.734 & 2.356 & 0.743 & No \\
24 h/48 h & 0.015 & 0.491 & 2.356 & 0.876 & No \\
Tukey's d critical value: & & & 3.331 & & \\
\hline
\end{tabular}

Table 7. Statistical descriptive parameters for Detaseal function (Detax)

\begin{tabular}{lcccc}
\hline & Minimum & Maximum & Mean & Standard deviation \\
\hline Immediately & 2.220 & 3.100 & 2.690 & 0.212 \\
After 24 h & 2.190 & 3.090 & 2.670 & 0.212 \\
After 48 h & 2.170 & 3.070 & 2.647 & 0.212 \\
\hline
\end{tabular}

Table 8. ANOVA repetition analysis for Detaseal

\begin{tabular}{lccccccc}
\hline \multicolumn{1}{c}{ Source } & DF & Sum of squares & Mean squares & F & Pr $>$ F & Adj. Pr $>$ F G-G & Adj. Pr $>$ F H-F \\
\hline Repetition & 2 & 0.094 & 0.047 & 790.074 & $<0.0001$ & $<0.0001$ & $<0.0001$ \\
Error & 198 & 0.012 & 0.000 & & & & \\
\hline
\end{tabular}

Table 9. Tukey test to establish a difference between time intervals (Detaseal function Detax)

\begin{tabular}{lccccc}
\hline \multicolumn{1}{c}{ Contrast } & Difference & Standardized difference & Critical value & Pr $>$ Diff & Significant \\
\hline now/24 hours & 0.043 & 1.444 & 2.356 & 0.320 & No \\
now/48 hours & 0.021 & 0.696 & 2.356 & 0.766 & No \\
$24 \mathrm{~h} / 48 \mathrm{~h}$ & 0.022 & 0.747 & 2.356 & 0.736 & No \\
Tukey's d critical value: & & & 3.331 & \\
\hline
\end{tabular}

Table 10. Statistical descriptive parameters for Sta-seal $\mathrm{f}$ (Detax)

\begin{tabular}{lcccc}
\hline & Minimum & Maximum & Mean & Standard deviation \\
\hline Immediately & 2.200 & 3.230 & 2.753 & 0.249 \\
After 24 h & 2.080 & 3.110 & 2.579 & 0.248 \\
After 48 h & 2.080 & 3.090 & 2.569 & 0.247 \\
\hline
\end{tabular}


Table 11. ANOVA repetition analysis for Sta-seal $\mathrm{f}$

\begin{tabular}{lccccccc}
\hline \multicolumn{1}{c}{ Source } & DF & Sum of squares & Mean squares & F & Pr $>$ F & Adj. Pr $>$ F G-G & Adj. Pr $>$ F H-F \\
\hline Repetition & 2 & 2.145 & 1.073 & 1255.161 & $<0.0001$ & $<0.0001$ & $<0.0001$ \\
Error & 198 & 0.169 & 0.001 & & & & \\
\hline
\end{tabular}

Table 12. Tukey test to establish a difference between time intervals (Sta-seal $\mathrm{f}$ Detax)

\begin{tabular}{lccccc}
\hline \multicolumn{1}{c}{ Contrast } & Difference & Standardized difference & Critical value & Pr $>$ Diff & Significant \\
\hline now/24 hours & 0.184 & 5.244 & 2.356 & $<0.0001$ & Yes \\
now/48 hours & 0.175 & 4.966 & 2.356 & $<0.0001$ & Yes \\
$24 \mathrm{~h} / 48 \mathrm{~h}$ & 0.009 & 0.269 & 2.356 & 0.961 & No \\
Tukey's d critical value: & & & 3.331 & & \\
\hline
\end{tabular}

Table 13. Mean values of the tested materials.

\begin{tabular}{lcccc}
\hline & GC Iso functional sticks & Kerr impression compound green & Sta-seal f & Detaseal function \\
\hline immediately & 2.960 & 2.935 & 2.753 & 2.690 \\
after 24 h & 2.937 & 2.935 & 2.579 & 2.670 \\
after 48 h & 2.923 & 2.935 & 2.569 & 2.647 \\
\hline
\end{tabular}

by other authors. The type of the polymerization reaction and the release of the side products in the condensation silicones show a change in their volume. The established significant difference in linear stability of the condensation silicones during the first 24 hours was confirmed by other authors. ${ }^{19,20}$ The deviation and linear change are not the same in the three dimensions of the impression. ${ }^{21,22}$ In the additive reaction due to the breakage of double and triple bonds in the polymer chain, such side product is not observed and the volume accuracy is preserved. ${ }^{14,24}$ Our investigation confirmed the statement that additive type silicones are stable up to 48 hours after impression taking. ${ }^{18,19}$

The resulting hardness of the two thermoplastic materials confirms their basic application in unretentive alveolar ridges, whereas the elasticity of the two silicone materials allows their application in retentive. ${ }^{14,15,24}$ To preserve the properties of the thermoplastic materials tested, it is advisable to melt them at a temperature specified by the manufacturer. ${ }^{23,24}$ The thermoplastic impression materials have impressed the projection of the gingivobuccal sulcus more widely than the silicones. A similar study also shows that thermoplastic materials impressed the area wider but also shorter than A-silicone. ${ }^{7}$ In literature, the impression compound possesses $0.3-0.5 \%$ linear shrinkage, which is not confirmed of our results. ${ }^{15}$ In a combined study, it was found that the impression compound gave the largest variation in width, the wax - in the area. ${ }^{8}$

When comparing the final result of complete dentures made after impression taking with impression compound and A-silicone, no statistically significant difference was found. ${ }^{22}$ Some authors observed a significant difference in retentive effect using impression compound and A-silicone, ${ }^{16}$ others did not detect it ${ }^{17}$. For patients' satisfaction is important the stability, phonetics, volume of a construction and balanced occlusion, which are indirectly related to the type of the impression material. ${ }^{4,5,16}$

\section{CONCLUSION}

Border molding procedure is important part of complete dentures fabrication and it is related to the final result. Depending of anatomical features can be used different impression materials. Good manipulative qualities and measured accuracy in laboratory tests define these materials as very good for using in border molding procedure and represent a method of choice in the clinical shaping of the edge of the individual impression tray. The statistically significant difference in condensation type silicone is not clinically significant. 


\section{AKNOWLEDGEMENTS}

This study was funded by project No 12/2017 from the Medical University of Plovdiv, Bulgaria.

\section{REFERENCES}

1. Laurina L, Soboleva U. Construction faults associated with complete denture wearers' complaints. Stomatologija 2006; 8(2): 61-4.

2. Jivraj S, Chee W, Corrado P. Treatment planning of the edentulous maxilla. Br Dent J 2006; 201(5): 261-79.

3. Klein IE, Broner AS. Complete denture secondary impression technique to minimize distortion of ridge and border tissues. J Prosthet Dent 1985; 54(5): 660-4.

4. Simon P, Critchlow B. Reducing the risk of failure in complete denture patients. Dent Updat 2012; 39: 427-36.

5. Kaur S, Datta K, Gupta R. Comparative analysis of the retention of maxillary denture base with and without border molding using zinc oxide eugenol impression paste. Indian J Dent 2016; 7(1): 1-12.

6. Duncan JP, Taylor TD. Teaching an abbreviated impression technique for complete dentures in an undergraduate dental curriculum. J Prosthet Dent 2001; 85(2): 121-5.

7. Gupta R, Luthra RS. Comparison of border morphology recorded using two border molding materials. J Adv Med Dent Sci 2015; 3(4): 122-4

8. Arora AK, Goyal I. Comparative evaluation of reproducibility of peripheral tissues produced by different border molding materials in edentulous patients:An in vivo study. J Indian Prosthodont Soc 2015; 15(2): 102-10.

9. Popov N. Clinic of Prosthetic Dentistry. Clinical dental prosthesis. Sofia, Medicine and Physical Education, 1999: 221-30.

10. Lindhe JE, Bressan D, Cecchinato E, et al. Bone tissue in different parts of the edentulous maxilla and mandible. Clin Oral Implants Res 2013; 24(4): 372-7.

11. Slavchev D. [Reproduction of the arch of the upper complete denture after analysis of frontal teleroentgenography.] [Dissertation], Plovdiv, Bulgaria, 2005 (Bulgarian).

12. Filchev D. [Graphical and computer design of the distal teeth of complete dentures.] [Dissertation], Sofia, Bulgaria, 2013 (Bulgarian).
13. Yordanov Y, Uzunov K, Fakih H. [Handbook of anatomy and anthropology for dentists] Artgraph, Sofia, 2012; 33: 57-66, 233-4 (Bulgarian).

14. Kissov Ch. Impression materials and methods in fixed dentistry. Sofia: Index; 1998: 31-50.

15. O'Brien WJ. Dental materials and their selection. 2002; 13867.

16. Al-Judy H. Comparison of the effect of sectional border molding using different molding and final impression materials on the retention of maxillary complete denture bases. IOSR Journal of Dental and Medical Sciences 2279-0861.2015; 14(7): 35-40.

17. Yarapatineni R, Vilekar A, Kumar JP, et al. Comparative evaluation of border molding, using two different techniques in maxillary edentulous arches - an in vivo study. J Int Oral Health 2013; 5(6): 82-7.

18. Chandran DT, Jagger DC, Jagger RG, et al. Two- and three-dimensional accuracy of dental impression materials: effects of storage time and moisture contamination. Biomed Mater Eng 2010; 20(5): 243-9.

19. Levartovsky S, Levy G, Brosh T, et al. Dimensional stability of polyvinyl siloxane impression material reproducing the sulcular area. Dent Mater J 2013; 32(1): 25-31.

20. Singh K, Sahoo S, Prasad KD, et al. Effect of different impressions techniques on the dimensional accuracy of impresions using various elastomeric impression materials: An in vitro study. J Contemp Dent Pr 2012; 13(1): 98-106.

21. Steinhäuser-Andresen S, Detterbeck A, Funk C, et al. Pilot study on accuracy and dimensional stability of impression materials using industrial CT technology. J Orofac Orthop [Internet] 2011; 72(2): 111-24.

22. 22. Price RB, Gerrow JD, Sutow EJ, et al. The dimensional accuracy of 12 impression material and die stone combinations. Int J Prosthodont 1991; 4(2): 169-74.

23. Starcke E. A historical review of complete denture impression materials. J Am Dent Assoc. 1975; 91(5): 1037-41.

24. Jayaraman S, Singh BP, Ramanathan B. Fabrication of complete/partial dentures (different final impression techniques and materials) for treating edentulous patients (Protocol). Cochrane Libr. 2016; 6: 1-16.

25. Chopra S, Gupta NK, Tandan A, et al. Comparative evaluation of pressure generated on a simulated maxillary oral analog by impression materials in custom trays of different spacer designs: An in vitro study. Contemp Clin Dent 2016; 7(1): 55-60. 


\section{Лабораторное исследование точности оттискных материалов для функционального формирования краёв}

\section{Добромира Шопова, Диян Славчев}

Кафедра ортопедическоой стоматологии, Факультет дентальной медиины, Медицинский университет-Пловдив, Болгария

Адрес для корреспонденции: Добромира Шопова, Кафедра ортопедическоой стоматологии, Факультет дентальной медиины, Медицинский университет-Пловдив, бул. „Христо Ботев" № 3, 4000 Пловдив, Болгария;

E-mail: dent.shopova@gmail.com; Tel: +359887417078

Дата получения: 01 июня 2018 Дата приемки: 28 февраля 2019

Дата публикации: 30 сентября 2019

Ключевые слова: функциональное формирование, оттискные материалы, полные зубные протезы

Образец цитирования: Shopova D, Slavchev D. Laboratory investigation of accuracy of impression materials for border molding. Folia Med (Plovdiv) 2019;61(3):435-43 doi: 10.3897/folmed.61.e39351
Введение: Функциональное формирование края индивидуальной ложки является важным этапом протезирования беззубых челюстей, от которого часто зависит конечный результат лечения. Классические термопластичные оттискные материалы функционального формирования обладают положительными качествами, которые делают их предпочтительными для врачей изза их жёсткости, неограниченного времени манипуляции и высокой чёткости оттиска. Современные силиконовые функциональные оттискные материалы имеют длительное время обработки и адекватную вязкость, что позволяет стоматологам проводить функциональные тесты.

Цель: Определить точность различных оттискных материалов для функционального формирования индивидуальных ложек.

Материалы и методы: В лаборатории были испытаны четыре типа оттискных материалов для функционального формирования: термопластичный материал Kerr impression compound green sticks и GC Iso functional sticks, силиконовый материал Detaseal function и конденсационный силикон sta-seal f. Была использована модифицированная индивидуальная оттискная ложка, изготовленная авторами, которая обеспечивала лабораторную нагрузку и стабильность. Было снято десять оттисков, и их края были измерены в 10 точках три раза - сразу после затверждения / эластификации и через 24 часа и 48 часов после затверждения / эластификации.

Результаты: Результаты были проанализированы с помощью дисперсионного анализа ANOVA repetition для сравнения более двух средних групп, которые обнаружили статистически незначимое различие в точности трёх оттискных материалов для функционального формирования, кроме силикона C-type.

Выводы: Хорошие качества обработки и измеренная точность при лабораторных испытаниях позволяют утверждать, что эти оттискные материалы очень хороши для процедур функционального формирования. 